similar to those used in practice. At high current densities, the ions are transported through 'Permaplex' $C-10$ and $A-10$ membranes faster than they can get to the membrane interface. At low current densities the transport numbers decrease with decreasing current density because concentration diffusion partially counteracts the electrical migration. When this effect is allowed for, the true transport number of the sodium ion in 'Permaplex' $C-10$ in $0 \cdot 1 \mathrm{~N}$ solution is found to be 0.98 , and its diffusion coefficient $8.1 \times 10^{-8} \mathrm{~cm}^{2} / \mathrm{sec}$.

J. F. DUNCAN

\section{RAINFALL STATISTICS IN THE BELGIAN CONGO}

$\mathbf{N}$ standard books of climatology published even since 1945 laments are to be found about the scanty nature of the data on the rainfall of equatorial forest areas. This reproach is now being rapidly removed and nowhere more rapidly than in the Belgian Congo, where the National Agronomic Institute has published during the past fow years several detailed papers by F. Bultot. In a recent publication*, M. Bultot presents the first analysis, using modern statistical methods, of the rainfall regime in an equatorial continental tropical region without a monsoon wind regime. Rainfall in the Congo falls in scattered thundery downpours. The data used cover twenty-nine years for Eala in the north-west and for varying periods of more than twenty years for fourteen other stations in the area.

The problems investigated are the frequency of falls of different intensity, the probability for two or more days of rain exceeding $15 \mathrm{~mm}$. to occur in succession, and the variation in the intensity of rainfall during $a$ shower. It is found that rain of more than $0.1 \mathrm{~mm}$. falls on one day in four and that the number of days in a year of $15 \mathrm{~mm}$. or more of rain is less than ten or more than sixty on less than one year in twenty, and the number of days of $50 \mathrm{~mm}$. and $80 \mathrm{~mm}$. can only exceptionally exceed twelve and four, respectively. There is a marked annual variation, corresponding to the movement with the Sun of the tropical rainbelt, of days with $15 \mathrm{~mm}$. or more of rain and a much less marked one, except in the central Congo where it vanishes, of days of $50 \mathrm{~mm}$. or more.

A very interesting fact is that there is no per. sistence of heavy rainfalls. The probability, in fact, that $15 \mathrm{~mm}$. or more will fall on the day following one with such amount is practically equal to the overall probability of a daily fall of that amount. In temperate regions there is appreciable persistence for rain days as a whole, though the degree of persistence for amounts of $15 \mathrm{~mm}$. or more does not appear to have been investigated. The daily maximum expected to be exceeded only once in ten years is about $120 \mathrm{~mm}$. and once in fifty years is $150 \mathrm{~mm}$. It is pointed out that in Ireland the corresponding values are $64 \mathrm{~mm}$. and $81 \mathrm{~mm}$.

Study of a number of individual falls shows that the rate of rainfall is heaviest within a quarter of an hour from the beginning and rarely exceeds $2 \mathrm{~mm}$. per minute. Only about 25 per cent of all falls

- Publications de l'Institut National pour l' Etude Agronomique du Congo Belge : Etude Statistique des Pluies Intenses en un Polnt et sur une Aire au Congo Belge et au Ruanda-Urundi. (Bureau ClimatoInstitut National pour l'Etude Agronomique du Congo Belge, 1956.) n.p. continue for more than four hours. The common opinion that tropical showers almost always occur in the afternoon is incorrect. It is found, however, that at most places there are relatively few showers during the morning. The afternoon showers are shorter and more intense than those at night. Finally, in a restricted study of area rainfall it is found that over areas up to $175 \mathrm{sq} . \mathrm{km}$. the frequencies of a given amount diminish exponentially with the area.

There is no discussion of the synoptic meteorology of rain. Perhaps in a future publication M. Bultot will investigate such matters as the incidence of showers or absence of showers over wide areas and the corresponding stream-lines of wind flow.

G. A. BULL

\section{LVOV GEOLOGICAL SOCIETY}

THE Lvov Geological Society celebrated in 1956 the tenth anniversary of its foundation. Lvov Geological Society is attached to Ivan Franco's State University of Lvov, founded in 1661. There the teaching of geology began at the end of the eighteenth century, when the chair of geognosy and oryktognosy was founded, no doubt under the impulse of the prevalent Wernerianism. In 1852 a mineralogical museum and in 1864 a chair of mineralogy were established. The first professor of mineralogy was Ferdinand Zirkel (1838-1912), the distinguished pioneer of microscopical petrography. It was during his residence in Lvov (1864-68) that Zirkel published his "Lehrbuch der Petrographie" (1866).

The Lvov Geological Society is now a very vigorous institution, comprising more than a hundred and twenty members. It is subdivided into a mineralogical section, presided over by Prof. E. K. Lazarenko, and a regional geology section by Prof. O. S. Vyalov. There is also a branch at the Chernovtzy State University. The principal object of the Society is the promotion of the study of geology, petrology, mineralogy and mineral deposits of the Western Ukraine, as well as other parts of the Soviet Union. It is interesting to note, however, that many contributors to its periodical publication reside in places distant from Lvov and even outside the Soviet Union, for example, in Bulgaria, China and Bolivia. The Society, besides its normal activities, has two special functions, namely, the organization of special surveys or studies in either pure or applied geology, and also of conferences. The Society has already undertaken the following surveys: a geophysical survey of Lvov region; a geological and geomorph. ological survey of certain Carpathian regions; $a$ petrographical and mineralogical study of igneous and sedimentary rocks; and finally, a specially organized survey of the Eastern Transbaikal region in Siberia. The conferences organized by the Society comprise the subjects of tectonics, stratigraphy, petrology, economic geology and history of geology.

The publications of the Society are: (1) Mineralogichesky Sbornik (Mineralogical Magazine), each annual volume of some 400 pages containing about forty original papers; (2) Trudy (Transactions) of Lvov Geological Society, comprising geological, petroleum geology and petrographical series; (3) Geologichesky Sbornik (Geological Magazine), replacing Trudy since 1955 ; (4) monographs on the petrology of the Ukrainian crystalline massif, granite plutons of Kazakhstan, migration of oil, tourmaline, bentonite clays, the Eastern Transbaikal region and Aldan 